Journal of Advances in Sports and Physical Education

Abbreviated Key Title: J Adv Sport Phys Edu ISSN 2616-8642 (Print) |ISSN 2617-3905 (Online) Scholars Middle East Publishers, Dubai, United Arab Emirates

Journal homepage: https://saudijournals.com/jaspe

Original Research Article

\title{
Changes in Some Immunoregulatory and Haemostatic Cell Counts in Pre- and Post-Exercise
}

\author{
Chukwurah Ejike Felix ${ }^{1 *}$, Udeji Louis Oguguo ${ }^{2}$, Chukwurah Felix Chinedum ${ }^{3}$ \\ ${ }^{1}$ Haematology \& Immunology Unit, Department of Medical Laboratory Sciences, Faculty of Health Sciences \& Technology, Ebonyi State University, \\ Abakaliki, Nigeria \\ ${ }^{2}$ Department of Medical Laboratory Sciences, Faculty of Health Sciences \& Technology, Ebonyi State University, Abakaliki, Nigeria \\ ${ }^{3}$ Shenyang Medical College, Shenyang Liaoning P.R. China/Dept of Surgery, Enugu State University Teaching Hospital, Enugu, Nigeria
}

DOI: $10.36348 /$ jaspe.2020.v03i05.002

| Received: 01.05.2020 | Accepted: 09.05.2020 | Published: 12.05.2020

*Corresponding author: Chukwurah Ejike Felix

\section{Abstract}

Introduction: There has been increasing awareness on the health benefits of physical activities or exercise and this led to community-based initiatives aimed at improving health and general well being. The duration of exercise, genetic factors, the physiologic characteristics and lifestyle of individuals are closely related to acute and chronic differences in hematologic parameters. Aim: The intent of this study was to investigate some haematological changes (PCV, TWBC and platelet counts) in male athletes pre- and post-exercise. Methods: A cross-sectional, longitudinal study was carried out on a total of 50 athletes who engaged in community-based regular fitness exercise for more than six months. The candidates were sampled before and immediately after strenuous exercise and PCV, TWBC and platelet counts assessed using standard methods. The TWBC and platelets count differed significantly ( $p>0.05$ ) between pre- and post-exercise. No significant difference was observed in the PCV among the groups. Conclusion: In summary, our findings show that exercise improved significantly the cellular level of total white blood cells and platelet count. This consequently is of great importance to the immune defense and haemostatic function. There is need for future large scale evidence-based research aimed at advocacy, awareness creation and prioritizations in primary/preventive health policy formulation.

Keywords: Pre- and post-exercise, PCV, TWBC, platelet count, health implication.

Copyright @ 2020: This is an open-access article distributed under the terms of the Creative Commons Attribution license which permits unrestricted use, distribution, and reproduction in any medium for non-commercial use (NonCommercial, or CC-BY-NC) provided the original author and source are credited.

\section{INTRODUCTION}

The world over, interventions to improve health through physical activities/exercises are now prominent and community-based initiatives targeted toward informational, behavioural, social, policy, and environmental approaches are becoming increasingly appreciated [1]. There has been increasing awareness of the positive health implications of exercise on physical, psychological and other chronic health conditions and is included in the public health interventions for improving health and general well-being. The Global Advocacy Council for Physical Activity, International Society for Physical Activity and Health the Toronto charter called for action on physical activity since 2010 [2]. This is followed by community-based exercise and motivational intervention on physical fitness in the management of some chronic diseases [3-5]. There were evidenced-based interventions and benefits of physical activities [6-9] and few adults in Nigerian big cities are beginning to key into these important health interventions. There is need therefore for improvement as only the minority of elites is aware of the importance of exercise on general well-being and reduction in mortality.

Evidence suggests that physical exercise is associated with beneficial maximal oxygen uptake $\left(\mathrm{VO}_{2} \mathrm{max}\right)$ and hence beneficial in weight loss [10] and in the management of Diabetes [11], depression and stress [4, 12], osteoporosis [13], cardiovascular, immune, and endocrine system. Daily physical activity is essential in maintaining a healthy weight and reducing risk of chronic diseases and provides antioxidant production, promote blood flow and transport of nutrients and effector molecules and cells [14, 15] necessary for haemostasis, oxygen transport and immunity [16]. Hence, several studies were dedicated to examine the blood hemodynamic and haemostasis after exercise whether for leisure, intense or strenuous. 
Regular exercise and physical activity are considered as an important regulator of blood cells and their functions $[17,18]$. On the other hand, physical inactivity and sedentary lifestyles is often accompanied by hematologic disorders such as hypovolemia, hematocrit (HCT) and $\mathrm{pH}$ imbalance [19]. Many individuals choose to exercise outdoors where they can congregate in groups, socialize, and enhance well-being [20] without knowing there health status. Nevertheless, for these numerous benefits to be attained by an individual, many anabolic and catabolic changes occur in the body which may bear on the normal functions of the cellular and molecular components of the blood; hence the need for this study.

Conflicting reports abound on the effects of exercise and stress on the redistribution of haematological parameters at different bouts of exercise in advanced countries [21-26] with dirt of information in people from our environment. This work therefore, examines the effect of individual exercise on some haematological/immunological parameters using community-based fitness group of Ebonyi State University students/staff as a sentinel.

\section{METHODS}

\section{Subjects and Sampling}

This cross-sectional, longitudinal study was conducted on local community-organized athletes at Presco Fitness Training and Gym Centre, Abakaliki. Written informed consent was obtained from each participant and study protocol was approved by Ebonyi
State University Ethical Review Committee. Strict anonymity was observed throughout the study and intervention programmed aimed at educating the participants on the benefit of the physical training exercise on general health and the implications of the study was instituted. Sample size was calculated using the method of Cochran [27].

A total of 50 athletes (all males) between the ages of 18-60 years who engaged in community organized intensive physical fitness exercise for not less three months were sampled pre- and post- exercise. Athletes with less than three most regular exercises and who withdrew consent were excluded. Two milliliters of blood was collected from each participant into EDTA bottles and process within two hours.

\section{Measurements of Variables}

The pack cell volume (PCV), total white blood cell count (TWBC) and platelete count were done without preservation within 2hour using standard methods. Data were analyzed using Pearson correlation and Student T-test, adapted from Statistical Package for Social Sciences (SPSS) version 22 and Microsoft excel software. Statistical significance was set at $\mathrm{p}<0.05$.

\section{RESULTS}

The mean $( \pm \mathrm{SD})$ values for pre- and post exercise values were presented in Table-1. The TWBC and platelets count differed significantly between preand post-exercise $(\mathrm{p}>0.05)$. No significant difference was observed in the PCV among the groups.

Table-1: Comparison of Mean ( \pm SD) values of Pre- and Post Exercise among participants

\begin{tabular}{|l|l|l|l|l|}
\hline Variables & Pre-exercise $(\mathbf{n}=\mathbf{5 0})$ & Post-exercise $(\mathbf{n}=\mathbf{5 0})$ & $\boldsymbol{r}$ & $\boldsymbol{p}_{\text {-value }} \boldsymbol{a}^{\boldsymbol{a}}$ \\
\hline PCV $(\boldsymbol{\%})$ & $45.90 \pm 6.35$ & $45.88 \pm 6.19$ & $0.669^{*}$ & 0.978 \\
\hline TWBC count $(\times \mathbf{1 0} / \mathbf{l})$ & $6.73 \pm 2.45$ & $10.45 \pm 4.22$ & 0.213 & 0.000 \\
\hline PLT count $(\times \mathbf{1 0} / \mathbf{I})$ & $186.92 \pm 64.35$ & $268.04 \pm 106.28$ & $0.479^{*}$ & 0.000 \\
\hline
\end{tabular}

Key: PCV: Packed cell volume, TWBC: total white blood cell count, PLT: platelet count

\section{DISCUSSION}

Physical activity through regular exercise is now being increasing appreciated worldwide even in developing counties and the positive impact on physiological, psychological and general health outcomes has been documented [28, 29]. Regular exercise improves the efficiency of cardiovascular [30], haemostatic and immunoregulatory systems [31] and can help mange over chronic illnesses [32]. Despite these benefits, good majority of adults in Nigeria do not meet recommendations for physical activity, and over $80 \%$ of adults universally are insufficiently active [33]. Sedentary life or physical inactivity has been adjudged the fourth risk factor for mortality globally [32] leading to risk factor for mortality globally.

Notable variations in blood count during exercises has been documented and is widely used as an indicator to evaluate the effect of exercise on the function of body systems. Blood is composed of three main cell types; red blood cells (RBCs) or erythrocytes, platelets and white blood cells (WBCs) or leukocytes [28]; associated with oxygen transport needed in efficient energy production for muscle contraction and sustained contractions during the prolonged physical activity and exercise, immunological defenses and haemostatic functions [16]. It has been documented that reduction in any of these functional cellular components of blood may impact negatively on physical performance and general well being [31].

Variations in haematological parameters in peripheral blood during and after physical activity or exercise have been documented [28,32]. It has been observed that duration of exercise, genetic factors, the physiologic characteristics and lifestyle of subjects are closely related to acute and chronic differences in hematologic parameters and might account for the inconsistencies in results $[8,34,35]$. 
In this study, significant elevation of TWBC and platelets were observed, while PCV was not significant. Insignificant variation in PCV was in disparity with the previous finding [36] on athletes in four weeks intensive training and in agreement with the study of Green et al., (1991) [37]. It has been shown that active participation in a short bout of muscular exercise caused marked leucocytosis which is evident in this study. Previous studies [34-35] indicate that short bouts of physical exercise on a bicycle ergometer massively increased leucocyte counts in both trained and untrained athletes. The leucocytosis caused by exercise could possibly be due to a number of factors; actions of catecholamines, cortisol, demargination, neuronal transmitters and peptides or purine chemical transmitters. In any of this mechanism, large numbers of cells which at rest, are adherent to the walls of blood vessels (endothelium), i. e., marginated pool, are suddenly released into circulation [38]. Demargination could also be due to the effects of stress hormones, such as adrenaline, which decreases the adherence of leucocytes to the endothelium via interaction with \$receptors on both cell types [37]. Previous studies support this finding. White blood cells are involved in all aspects of the immune system. The immune system therefore, can be activated directly via cells or the release of soluble factors.

Significant elevation in platelet count observed in this study is consistent with previous findings [39] in anaerobic exercise. Platelets number and functions has been reported to be enhanced by increasing the secretion of epinephrine during high-intensity interval training.

\section{CONCLUSION}

In summary, our findings show that exercise improved significantly the cellular level of total white blood cells and platelet count. This consequently is of great importance to the immune defense and haemostatic function. There is need for future large scale evidence-based research aimed at advocacy, awareness creation and prioritizations in primary/preventive health policy formulation.

Acknowledgment: We gratefully acknowledge the help of all the participant who took part in the study.

Conflict of interests: The authors declare that they have no conflict of interest.

\section{REFERENCES}

1. Powell, K. E., \& Paffenbarger Jr, R. S. (1985). Workshop on epidemiologic and public health aspects of physical activity and exercise: a summary. Public Health Reports, 100(2), 118-126.

2. Global Advocacy Council for Physical Activity, International Society for Physical Activity and Health the Toronto charter for physical activity: a global call to action. 2010 May
20; http://www.globalpa.org.uk/pdf/torontocharter -eng-20may2010.pdf [accessed March 19, 2020].

3. Ensari, I., Sandroff, B. M., \& Motl, R. W. (2016). Effects of single bouts of walking exercise and yoga on acute mood symptoms in people with multiple sclerosis. International journal of $M S$ care, 18(1), 1-8.

4. Anderson, E. H., \& Shivakumar, G. (2013). Effects of exercise and physical activity on anxiety. Frontiers in psychiatry, 4, 27.

5. Gallé, F., Di Onofrio, V., Miele, A., Belfiore, P., \& Liguori, G. (2019). Effects of a communitybased exercise and motivational intervention on physical fitness of subjects with type 2 diabetes. European journal of public health, 29(2), 281-286.

6. Slentz, C. A., Houmard, J. A., \& Kraus, W. E. (2009). Exercise, abdominal obesity, skeletal muscle, and metabolic risk: evidence for a dose response. Obesity, 17(S3), S27-S33.

7. Poole, L., Hamer, M., Wawrzyniak, A. J., \& Steptoe, A. (2011). The effects of exercise withdrawal on mood and inflammatory cytokine responses in humans. Stress, 14(4), 439-447.

8. Heath, G. W., Parra, D. C., Sarmiento, O. L., Andersen, L. B., Owen, N., Goenka, S., ... \& Lancet Physical Activity Series Working Group. (2012). Evidence-based intervention in physical activity: lessons from around the world. The lancet, 380(9838), 272-281.

9. Meyer, J. D., Koltyn, K. F., Stegner, A. J., Kim, J. S., \& Cook, D. B. (2016). Influence of exercise intensity for improving depressed mood in depression: a dose-response study. Behavior therapy, 47(4), 527-537.

10. Gim, M. N., \& Choi, J. H. (2016). The effects of weekly exercise time on VO2max and resting metabolic rate in normal adults. Journal of physical therapy science, 28(4), 1359-1363.

11. Eriksson, J., Taimela, S., \& Koivisto, V. A. (1997). Exercise and the metabolic syndrome. Diabetologia, 40(2), 125-135.

12. Myers, J., Herbert, W. G., \& Humphrey, R. H. (2002). ACSM's Resources for Clinical Exercise Physiology: Musculoskeletal, Neuromuscular, Neoplastic, Immunologic, and Hematologic Conditions. Philadelphia: Lippincott Williams \& Wilkins. [Acessed online, Apr 1, 2020].

13. Tenforde, A. S., \& Fredericson, M. (2011). Influence of sports participation on bone health in the young athlete: a review of the literature. $P M \& R, 3(9), 861-867$.

14. Crane, J. D., MacNeil, L. G., Lally, J. S., Ford, R. J., Bujak, A. L., Brar, I. K., ... \& Tarnopolsky, M. A. (2015). Exercise- stimulated interleukin- 15 is controlled by AMPK and regulates skin metabolism and aging. Aging cell, 14(4), 625-634.

15. Anton, S. D., Hida, A., Mankowski, R., Layne, A., Solberg, L. M., Mainous, A. G., \& Buford, T. (2018). Nutrition and exercise in 
sarcopenia. Current Protein and Peptide Science, 19(7), 649-667.

16. Gjevestad, G. O., Holven, K. B., \& Ulven, S. M. (2015). Effects of exercise on gene expression of inflammatory markers in human peripheral blood cells: a systematic review. Current cardiovascular risk reports, $9(7), 34$.

17. Ludlow, A. T., Ludlow, L. W., \& Roth, S. M. (2013). Do telomeres adapt to physiological stress? Exploring the effect of exercise on telomere length and telomere-related proteins. BioMed research international, 2013; 115.

18. Büttner, P., Mosig, S., Lechtermann, A., Funke, H., \& Mooren, F. C. (2007). Exercise affects the gene expression profiles of human white blood cells. Journal of applied physiology, 102(1), 2636.

19. Booth, F. W., Roberts, C. K., \& Laye, M. J. (2011). Lack of exercise is a major cause of chronic diseases. Comprehensive Physiology, 2(2), 1143-1211.

20. Zulfarina, M. S., Sharkawi, A. M., AQILAH-SN, Z. S., Mokhtar, S. A., Nazrun, S. A., \& NainaMohamed, I. (2016). Influence of adolescents' physical activity on bone mineral acquisition: a systematic review article. Iranian journal of public health, 45(12), 1545-1557.

21. Landmann, R. M., Müller, F. B., Perini, C. H., Wesp, M., Erne, P., \& Bühler, F. R. (1984). Changes of immunoregulatory cells induced by psychological and physical stress: relationship to plasma catecholamines. Clinical and experimental immunology, 58(1), 127-135.

22. Mars, M., Govender, S., Weston, A., Naicker, V., \& Chuturgoon, A. (1998). High intensity exercise: a cause of lymphocyte apoptosis?. Biochemical and biophysical research communications, 249(2), 366-370.

23. Kobayashi, Y., Takeuchi, T., Hosoi, T., Yoshizaki, H., \& Loeppky, J. A. (2005). Effect of a marathon run on serum lipoproteins, creatine kinase, and lactate dehydrogenase in recreational runners. Research quarterly for exercise and sport, 76(4), 450-455.

24. Krüger, K., Lechtermann, A., Fobker, M., Völker, K., \& Mooren, F. C. (2008). Exercise-induced redistribution of $\mathrm{T}$ lymphocytes is regulated by adrenergic mechanisms. Brain, behavior, and immunity, 22(3), 324-338.

25. Prestes, J., de Ferreira, C. K. O., Dias, R., Frollini, A. B., Donatto, F. F., Cury-Boaventura, M. F., ... \& Curi, R. (2008). Lymphocyte and cytokines after short periods of exercise. International journal of sports medicine, 29(12), 1010-1014.

26. Neves, P. R. D. S., Tenório, T. R. D. S., Lins, T. A., Muniz, M. T. C., Pithon-Curi, T. C., Botero, J. P., \& Do Prado, W. L. (2015). Acute effects of high-and low-intensity exercise bouts on leukocyte counts. Journal of exercise science \& fitness, 13(1), 24-28.

27. Cochran, W. G. (1997). Sampling techniques $\left(3^{\text {rd }}\right.$ ed). New York: John Wiley \& sons.

28. Koç, H., Özen, G., Abanoz, H., \& Pulur, A. (2018). Comparative analysis of hematological parameters in well-trained athletes and untrained men. Pedagogy of Physical Culture and Sports, (5):260-264.

29. Kenney, W. L., Wilmore, J., \& Costill, D. (2015). Physiology of Sport and Exercise (6th ed.). Champaign, IL: Human Kinetics.

30. Mochizuki, K., Miyauchi, R., Misaki, Y., Kasezawa, N., Tohyama, K., \& Goda, T. (2012). Associations between leukocyte counts and cardiovascular disease risk factors in apparently healthy Japanese men. Journal of nutritional science and vitaminology, 58(3), 181-186.

31. Manabe, I. (2011). Chronic inflammation links cardiovascular, metabolic and renal diseases. Circulation Journal, $1111041460-$ 1111041460.

32. Orr, J., McGrouther, S., McCaig, M., \& Topping, C. (2019). Raising awareness about physical activity: pre-registrations student's action research finding. Physiotherapy Research and Reports, 2(2),16. https://doi.org/10.15761/PRR.1000127.

33. Mahaney MC, Brugnara C, Lease LR, et al., (2010). Genetic influences on peripheral blood cell counts: a study in baboons. Blood, 106: 12101214.

34. Nunes LA, Brenzikofer R, de Macedo DV (2010). Reference change values of blood analytes from physically active subjects. Eur J Appl Physiol, 110: 191-198.

35. Navalta JW, Sedlock DA, Park KS (2007). Effect of exercise intensity on exercise-induced lymphocyte apoptosis. Int J Sports Med, 28: 539542.

36. Bugdayci, G., Oguzman, H., Arattan, H. Y., \& Sasmaz, G. (2015). The use of reference change values in clinical laboratories. Clinical laboratory, 61(3-4), 251-257.

37. Green, K. J., Rowbottom, D. G., \& Mackinnon, L. T. (2002). Exercise and T-lymphocyte function: a comparison of proliferation in PBMC and NK celldepleted PBMC culture. Journal of Applied Physiology, 92(6), 2390-2395.

38. Pate, R. R., Pratt, M., Blair, S. N., Haskell, W. L., Macera, C. A., Bouchard, C., ... \& Kriska, A. (1995). Physical activity and public health: a recommendation from the Centers for Disease Control and Prevention and the American College of Sports Medicine. Jama, 273(5), 402-407.

39. Heber, S., \& Volf, I. (2015). Effects of physical (in) activity on platelet function. BioMed research international, 2015. 